Ann. Biol. anim. Bioch. Biophys., 1976, 16 (3), 27I-278.

\title{
THE DEVELOPMENT AND MATURATION OF THE OVARY
}

\author{
Hannah PETERS \\ The Finsen Laboratory, The Finsen Institute, \\ Copenhagen (Denmark)
}

\section{SUMMARY}

The role of the rete ovarii in early ovarian development has been discussed. The presence of the rete is necessary for the onset of meiosis as well as for early follicle formation.

Discussing the role of gonadotropin in follicle growth experiments are reported in which PMSG is injected into 3 week old mice. Follicle counts which distinguish between healthy and atretic follicles show that PMSG does not increase the total number of large follicles but changes the balance between healthy and atretic follicles. It is suggested that gonadotropin rather than stimulating resting follicles to grow, prevents already growing follicles from becoming atretic.

Finally, a short report is given on the development of the human ovary in childhood. The analysis of ca. 5o ovaries at different ages shows that the ovary during childhood is not a quiet organ but one that shows follicle growth at all ages.

\section{INTRODUCTION}

During the past few years a considerable amount of information on the development and maturation of the ovary has become available and I would like to choose three topics for discussion : First the influence of the rete ovarii on early ovarian development which recently has been elucidated, will be examined. Furthermore a report will be given on recent contributions to the question of the role of gonadotropin in follicle growth and atresia.

Finally the development of the human ovary in childhood will be discussed and the question will be raised whether it is a quiet organ or whether follicle development begins already early in life. 


\section{THE ROLE OF THE RETE OVARII IN THE ONSET}

\section{OF MEIOSIS AND FOLIICLE ORGANIZATION}

It is known that the primordial germ cells arise outside the gonadal anlage and migrate into the primordial gonad (EVERETT, I943; WITSCHI, I948). During their migration the germ cells divide mitotically and thereby increase their number. The germ cells of a female multiply for a time within the gonad but at a certain stage of development they cease to multiply and enter meiotic prophase. The stimulus to this change in behaviour of the female germ cell has remained obscure. Recent investigations have shown that the rete ovarii plays a decisive role in this process (Byskov, I 974 a). That the onset of meiosis is actually dependent on the presence of the rete ovarii was shown by Byskov (1974 $b$ ) in transplantation experiments. Gonads of I 2 day old mouse embryos were used. At this age the rete tubules have not yet grown into the gonad and meiosis has not started. The ovary was divided in such a way that one part contained extraovarian rete, while the other consisted of ovarian tissue without rete. The two parts were inoculated subcutaneously into adult nude mice. I4 days later the tissue was removed for examination. In the part of the ovary that contained rete, meiosis was induced, oocytes developed, oogonia were not seen any more. In the part that had grown without rete, meiosis was not induced, oogonia persisted, oocytes did not develop.

Detailed histologic examination of the ovaries of mice, cats, ferrets and mink at the time meiosis starts revealed heavily secreting rete cells and « open connections " between the rete system and the germ cells, allowing cellular contact (Byskov, I975). Those germ cells which come in contact with the rete cells first, enter meiosis first. Byskov suggests that rete cells free a factor which triggers meiosis. The rete cells are also essential in the organization and early formation of the follicles. If the rete is removed before the embryonal gonad is cultured under the skin of the nude mouse, follicles do not form while they develop normally when the rete is left in connection with the gonad before transplantation is done (BYskov, unpublished).

Thus in the young gonad the rete ovarii, its cells and possibly its secretion play a very critical role. It is essential for the triggering of meiosis as well as for the organization of the small follicles.

\section{FOLLICLE GROWTH}

Around the time of birth all oocytes are organized and enclosed in small follicles which form the pool of non-growing follicles. Soon after birth some begin to develop. Follicles start to grow at all times and at all ages. Though the number starting to develop is not the same at all ages (PEDERSEN, I973), the start of follicle development is continual. It has been found in infancy (PETERS, I969), in maturity, and even throughout pregnancy follicles begin to grow (GREENWALD, KEEVER and Grady, I967; Pedersen and Peters, I97I). The beginning of follicle growth must therefore be considered a continuum (PETERs et al., I975a). 
Though many follicles start to grow during infancy only a small number come to ovulation when the animal becomes mature. It is thought that FSH is responsible for the recruitment of a set of follicles chosen for ovulation (SchwarTz, I969; WEISCHEN, I973; GREENWALD, I974). The number of follicles coming to ovulation at the onset of maturity can be increased experimentally by injection of PMSG. This led to the proposal that follicles grow to a certain stage of development but are arrested to form a pool of large, reserve follicles from which they can be recruited (GREENWAL, I973).

Such a pool of large, non-growing follicles, if it exists, should be easily identifiable in follicle kinetic studies using a radioactive DNA precursor as a label. Resting large follicles could be identified in autoradiograms (ARG) in 2 ways:

I. In ARG prepared shortly after label injection (immediate ARG) the granulosa cells of large follicles that are resting would remain unlabelled.

2. In delayed ARG (i.e. those prepared some days after label injection) follicles that were growing when the label was injected but subsequently had become reserve follicles would be recognizable as follicles with heavily labelled granulosa cells. Immediate and delayed ARG have been prepared repeatedly during the immature as well as during the mature period in mice (PETERS and LEVY, I966; Pedersen, I973; Byskov, I974a). Unlabelled large follicles in immediate ARG or heavily labelled large follicles in delayed ARG have never been found. It must therefore be concluded that follicles grow sequentially without stopping at a point from which they again can be stimulated to grow.

\section{ATRESIA PREVENTING ACTION OF GONADOTROPIN}

We are then left with a dilemma : The fact is that injection of PMSG, during the late immature period, results in an excess number of follicles coming to ovulation (ZARRow and WILSON, I96I). Yet apparently a pool of arrested large follicles ready to start to grow after stimulation does not seem to reside in the ovary. What action might the gonadotropin have on the developing follicle ? We would like to propose, that the gonadotropin, rather than stimulating growth in arrested large follicles, in fact prevents actively growing follicles from atresia. This atresia preventing effect becomes evident from several observations.

During the immature period many follicles start to grow and by the time the mouse reaches the age of 3 weeks the ovary contains an unusually large number of large follicles (JONES and KROHN, I96I ; GATES, I97I). Most of these become atretic (INGRAM, I962) and only a small fraction ovulate at the onset of maturity about Io days later. Follicle atresia can set in at any stage of development; but it is rare in the early preantral stages while it is frequent in the late preantral and antral stages of development (HIMELSTEIN-BRAw et al., r976).

In order to evaluate the effect of PMSG on large follicles in 3 weeks old mice, 30 female mice from 6 litters were used. The litters were mixed shortly after birth, to make experimental and control animals comparable (PETERs et al., I973). When they were $2 \mathrm{I}$ days old the experimental mice were injected subcutaneously with 5 i.u. PMSG (Antex, Leo). Eight mice were sacrificed 6 hours later and II mice 
I 2 hours after the injection. Eleven animals were injected with $\mathrm{I} \mathrm{ml} \mathrm{NaCl}$ and sacrificed at the same time as the controls. In the serially sectioned ovaries large preantral (type 5) and antral follicles (type 6 and 7), (PEDERSEN and PETERs, I968) were counted; each section was surveyed and a follicle was counted when the nucleolus of its oocyte was visible. The follicles were divided into " healthy " and " atretic " ones. A follicle was considered to be atretic when a single pyknotic granulosa cell or more were seen on the cross section that was counted.

Already on casual histologic examination a difference between ovaries from control and experimental animals was noted. Ovaries from PMSG injected animals seemed to have considerably more " healthy " follicles already 6 hours after the injection and in the specimens 12 hours later, almost none of them were atretic. Quantitative analysis confirmed this impression (table I). In the control ovaries $3^{8} \mathrm{p}$. Ioo of the follicles were atretic. Six hours after PMSG injection their number was reduced to $I 5.8 \mathrm{p}$. IOo $(\mathrm{P}<0.00 \mathrm{I})$, while $\mathrm{I} 2$ hours after injection most of the follicles were healthy, only 5.2 p. Ioo were atretic. The total number of follicles, i.e. healthy plus atretic ones were not different from the controls. Apparently PMSG did not increase the number of large follicles but changed the balance between healthy and atretic ones. Atresia was prevented and follicles continued to grow.

\section{TABLE I}

Percentage of atretic follicles in normal and PMSG injected 21 days old mice

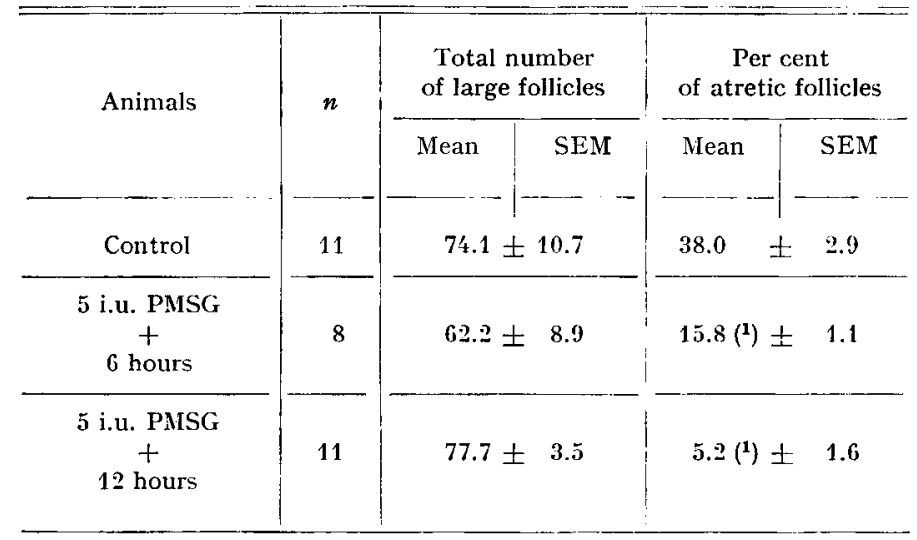

(1) Significantly different from control, $\mathrm{P}<0.001$.

The atresia preventing action of FSH on granulosa cells has also been shown in tissue culture (McNaTTy et al., I975 a). Human granulosa cells remained viable when cultured for ro days in a serum devoid of LH or Prolactin. However, when cultured in serum devoid of FSH, only $8 \mathrm{p}$. roo of the granulosa cells remained after Io days, while daily addition of FSH to the culture medium maintained the granulosa cells at numbers comparable to the controls. Thus also in culture growth of granulosa cells is maintained and atresia is prevented when FSH is present. 
That it is the microenvironment within the follicle itself that controls its growth has recently been shown. McNATTy et al., (I975 b) determined hormone levels in the fluid of follicles of different sizes and in the peripheral plasma in women throughout the menstrual cycle. They came to the conclusion that a precise sequence of hormonal changes occurs within the follicle during development, which determines its fate. A rise in FSH maintains the growth of granulosa cells in the early antral follicle which is stimulated to produce oestradiol. The oestrogen has a two fold effect : via the extraovarian pathway it influences the gonadotropin secretion and thereby the growth of subsequent follicles and via its intraovarian, intrafollicular action it stimulates the follicle which produces the estrogen (for further discussion see also BAIRD et al., I975).

\section{THE DEVELOPMENT OF THE HUMAN OVARY IN CHILDHOOD}

It is now well established that the development of the ovary between birth and maturity in all those mammals that have been examined is a very active one. The human ovary, however, is said to be quiescent and without follicle growth until the age of about Io years (v. WAGENEN and Srmpson, I973). And yet at menarche the ovary is a highly competent organ that produces hormones, releases eggs and responds to hormones for which it is the end organ. Thus it is likely that also in the human a very active development of the organ must take place during childhood. In order to investigate whether or not follicle growth, development and atresia are normal events in childhood, ovaries from children that had died accidentally or after a very brief acute disease have been examined histologically. These ovaries were considered to represent organs from normal children. Fifty-two ovaries from children between the ages of 2 months and II years were available (table 2 ).

TABLE 2

Human ovary in childhood

\begin{tabular}{|c|c|c|c|c|}
\hline \multirow[b]{2}{*}{ Age } & \multirow[b]{2}{*}{ Number } & \multicolumn{3}{|c|}{ Stage of ovarian development } \\
\hline & & Quiescent & $\begin{array}{c}\text { Early } \\
\text { Growth }\end{array}$ & $\begin{array}{l}\text { Actively } \\
\text { Growing }\end{array}$ \\
\hline $2-11 \mathrm{mo}$ & 17 & 0 & 2 & 15 \\
\hline $1-31 / 2$ yrs & 20 & 0 & 1 & 19 \\
\hline $4-11$ yrs & 15 & 0 & 0 & 15 \\
\hline Total & 52 & 0 & 3 & 49 \\
\hline
\end{tabular}

The development of the ovary was divided into 3 stages (PETERS et al., 1975).

I. The quiescent ovary consists of small resting follicles. An occasional preantral follicle might be seen. 
2. The ovary showing early growth contains besides small follicles also many preantral follicles.

3. The actively growing ovary contains preantral and large antral follicles as well as atretic follicles, derived from several stages of development.

In all 52 ovaries follicle growth was in progress. Quiescent ovaries in which follicle growth had not started were not seen. Three cases showed early growth and all others were actively growing ovaries with varying numbers of antral follicles. After the age of 6 years the number and size of the antral follicles increased (PETERS, HIMELSTEIN-BRAW and FABER, I976). Evidence of past growth, i.e. collapsed follicles and scars were always seen. It was therefore concluded that the normal development of the human ovary in childhood is also one in which growth and atresia are the normal events. This finding is in agreement with that in other primates (v. WAGENEN and SIMPSON, I973) in which the ovary and follicles develop throughout the immature period.

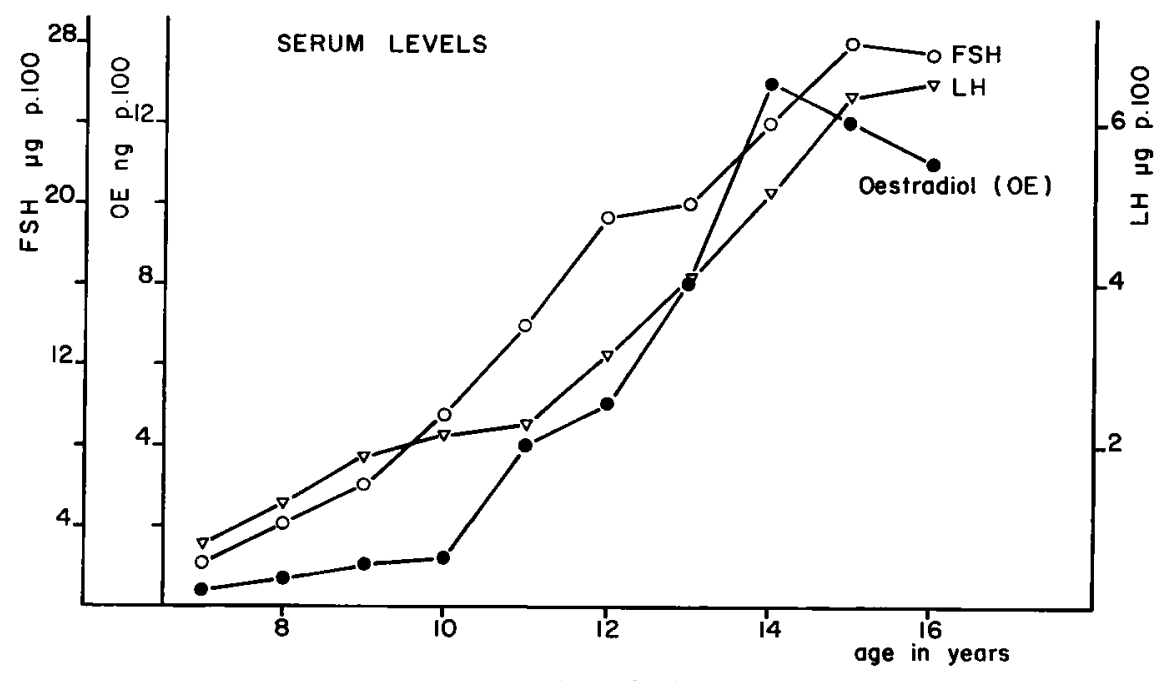

FIG. I. - Serim concentrations of FSH, LH and oestradiol in girls at different ages

(Redrawn from FAIMAN and WINTER (I974) with permission from the authors and John Wiley and Sons, Inc.)

Though follicles develop apparently at all ages during childhood it is not known yet how active the ovary is in terms of hormone production and response. Hormone levels in follicle fluid during childhood will necessarily have to remain unknown, but we have circumstantial evidence of the endocrine activity of the ovary. The hormone levels during childhood have recently been determined in serum (FAIMAN and WINTER, I974) and in urine (PRESL, I974). FSH levels in serum rise steadily throughout childhood (fig. I). The rise is marked after the age of 7 years, i.e. the age when the number and the size of antral follicles increase notably in the ovaries. The rise in oestradiol in serum is marked after the age of Io years (FAIMAN and Winter, I974) while PRESL (I974) recorded a continuous rise in oestrogen urinary 
excretion already after the age of 6 years. It is therefore likely that already in chilhood the human ovary responds to gonadotropins and produces hormones which reach the general circulation.

\author{
Sexual Maturation. 3rd Workshop. \\ August 31, September 3, 1975.
}

\title{
RÉSUMÉ
}

\section{DÉVELOPPEMENT E'T MATURATION DE L'OVAIRE}

Dans l'ovaire embryonnaire, la présence du rete ovarii est nécessaire pour l'apparition de la méiose et le début de la formation des follicules. Les cellules du rete doivent libérer un facteur qui déclenche la méiose.

Pour étudier le rôle des gonadotropines dans la croissance folliculaire on a injecté de la PMSG à des Souris de 3 semaines. Le dénombrement des follicules sains et atrétiques montre que la PMSG n'augmente pas le nombre de grands follicules, mais change le rapport entre follicules sains et atrétiques. Il semble que la gonadotropine ne stimule pas la croissance des follicules au repos, mais empêche les follicules en croissance de devenir atrétiques.

Enfin, l'étude de 50 ovaires humains à différents âges montre que pendant l'enfance l'ovaire $n$ 'est pas au repos. On observe une croissance folliculaire à tous les âges ( 2 mois à i I ans).

\section{REFERENCES}

Batrd D. T., Baker T. G., McNatty K. P., Neal P., 1975. Relationship between the secretion of the corpus luteum and the length of the follicular phase in the ovarian cycle. J. Reprod. Fert., 45, 6 r $1-619$.

Byskov A. G. S., I974a. Cell kinetic studies of follicular atresia in the mouse ovary. J. Reprod. Fert., 37, $277-285$.

Byskov A. G., 1974 b. Does the rete ovarii act as a trigger for the onset of meiosis? Nature, 252, 396-397.

BYskov A. G., I975. The role of rete ovarii in meiosis and follicle formation in the cat, mink and ferret. J. Reprod. Fert., 45, 20I-209.

EveretT N. B., x943. Observational and experimental evidences relating to the origin and differentiation of the definite germ cells in mice. J. Exp. Zool., 92, 49-9I.

Faiman C., Winter J. S. D., 1974. Gonadotropins and sex hormone pattern in puberty, p. 32 , in : Grumbach M. M., GRAve G. D., Mayer F. E. The control of the onset of puberty, John Wiley and Sons. London.

Gates A., I97I. Maximizing yield and developmental uniformity of eggs, 64-75, in : DanieL J. C., Methods in mammalian embryology. W. H. Freeman and Comp. San Francisco.

Greenwald G. S., I973. Distribution between developing reserve follicles in the cycling hamster. Ann. Biol. anim. Bioch. Biophys, 13, hors-série, r99-z10.

GreEnwald G. S., 1974. Role of FSH and LH in follicular development and ovulation, in : KNoBIL E., The hypothalamo-hypophyseal system. Section on Endocrinology. Am. Physiol. Soc., Washington. Section 7, Vol. 4, Part 2, p. 293-323.

Greenwald G. S., Keever J. E., Grady K. L., 1967. Ovarian morphology and pituitary FSH and LH concentration in the pregnant and lactating hamster. Endocrinology, 80, 85 I-856.

Himeistein-Braw R., Byskov A. G., Peters H., Faber M., I976. Follicular atresia in the infant human ovary. J. Reprod. Fert., 46, 55-59.

Ingram D, L., 1962. Atresia 247-274, in : Zuckerman S., The ovary, Vol. I, Academic Press. New York and London.

Jones E. C., Kronn P. L., I961. The relationship between age, numbers of oocytes and fertility in virgin and multiparous mice, J. Endocr., 21, 469-495.

McNatty K. P., Bernie J. G., Hunter W. M., McNeilly A. S., I975 a. The effects of antibodies to human gonadotrophins on the viability and rate of progesterone secretion by human granulosa cells in tissue culture, in : EDWARDS R. G., JoHNSON M. H., Physiological effects in immunity against hormones, Vol. 3, Cambridge University Press, Cambridge (in press). 
McNatty K. P., Hunter W. M., McNeiliy A. S., Sawers R. S., 1975 b. Changes in the concentration of pituitary and steroid hormones in the follicle fluid of human Graafian follicles throughout the menstrual cycle. J. Endocr., 64, 555-571.

Pedersen T., I973. Follicle growth in the mouse ovary, 36I-376, in : Bigarrs J. D., Schuetz A. W., Oogenesis. University Park Press, Baltimore. Butterworth, London.

Pedersen T., Peters H., r968. Proposal for a classification of oocytes and follicles in the ovary of the mouse. J. Reprod. Fert., 17, 555-557.

Pedersen T., Peters H., 197I. Follicle growth and cell dynamics in the mouse ovary during pregnancy. Fertil. Steril., 22, 42-52.

Peters H., I969. The development of the mouse ovary from birth to maturity. Acta Endocr., 62, 98-II6.

Peters H., Byskov A. G., Himelstein-Braw R., Faber M., i975. Follicle grow th: the basic event in the mouse and human ovary. J. Reprod. Fert. 45, 559-566.

Peters H., Byskov A. G., Lintern-Moore S., Faber M., Andersen M., I973. The effect of gonadotrophin on follicle growth initiation in the neonatal mouse ovary. J. Reprod. Fert., 35, r39-I4I.

Peters H., Himelstein-Braw R., Faber M., 1976. The normal development of the ovary in childhood. Acta Endocr. (in press).

Peters H., Levy E., I966. Cell dynamics of the ovarian cycle. J. Reprod. Fert., 11, 227-236.

PRESL J., 1974. Development of the oestrogen feedback. Avicenum Zdravotnické NakladateIstvi, Prag. Schwartz N. B., I969. A model for regulation of ovulation in the rat. Rec. Progr. Horm. Res., 25, I-54.

v. Wagenen G., Simpson M., I973. Postnatal development of the ovary in Homo Sapiens and Macaca Mulatta and induction of ovulation in the Macaque. Yale University Press, New Haven and London.

WELSChEN R., 1973. Amounts of gonadotrophin required for normal follicular growth in hypophysectomized adult rats. Acta Endocr., 72, 137-155.

Wiтschi E., I948. Migration of the germ cells of human embryos from the yolk sac to the primitive gonadal folds. Contrib. Embryol., 32, 67-80; Inst. Wash. Publ. No. 575.

ZARRow M. X., Wilson E. D., 196r. The influence of age on superovulation in the immature rat and mouse. Endocrinology, 69, 85I-855. 